\title{
Cypella cruenta (Iridaceae), the blood-stained Cypella
}

\author{
Leonardo Paz Deble ${ }^{1,2}$
}

\begin{abstract}
Resumo. Cypella cruenta (Iridaceae), a Cypella manchada de sangue. É descrita uma nova espécie de Cypella conhecida até o momento para a região da bacia do rio Camaquã, no sudeste do estado do Rio Grande do Sul, Brasil. A nova espécie, nomeada Cypella cruenta, pertence a seção Cypella, sendo morfologicamente similar a Cypella Alonsoana, C. exilis e C. fucata. Entretanto, C. cruenta é facilmente reconhecida por suas tépalas com a porção côncava e metade proximal da lâmina intensamente manchada de vermelho sangue, pela forma e dimensões dos estames e estilete com ramos mais curtos e com cristas menores, quando comparada com os táxons relacionados. Informações sobre distribuição geográfica, ecologia, conservação, usos e relações taxonômicas são fornecidas. Adicionalmente, são providenciadas ilustrações e uma tabela distintiva entre $C$. cruenta e suas espécies afins. Com a descrição da nova espécie, Cypella passa a compreender 32 espécies, 17 delas pertencentes a seção Cypella.

Palavras-chave: campos, nova espécie, Pampa, Tigridieae.
\end{abstract}

\begin{abstract}
Cypella cruenta (Iridaceae), the blood-stained Cypella. A new species of Cypella is described for the region of Camaquã river basin, in southeastern Rio Grande do Sul state, Brazil. The new species, named Cypella cruenta belongs to the section Cypella, being morphologically similar to the following species: Cypella Alonsoana, C. exilis and C. fucata. However, C. cruenta is easily recognized by its tepals with the concave portion and proximal half of the blade intensely painted in blood red, by the shape and size of the stamens and style with brief branches and with shorter crests, when compared with its similar taxa. Information on geographic distribution, ecology, conservation, uses and taxonomic relationships is provided. In addition, illustrations and a distinctive table among C. cruenta and its related species is presented. With the description of the new species, the genus Cypella now comprises 32 species, 17 of them belonging at section Cypella.
\end{abstract}

Key words: grasslands, new species, Pampa, Tigridieae.

In a recent collection trip, carried out in the Camaquã River basin region, in southeastern Rio Grande do Sul state, Brazil, three populations of a very peculiar Cypella were identified. Even with visible differences in the shape of the flowers and the color pattern of the tepals, these populations were initially linked to well-known $C$. exilis Ravenna (1981a: 492). After, with more accurate analysis of this material, jointly with the study of different individuals of $C$. exilis in southern Brazil and Uruguay, it was possible to recognize significant differences in the size and shape of stamens and style between these populations and C. exilis. Thus, it is necessary to describe herein a new species for the genus Cypella, belonging to the section Cypella. The new species is described, illustrated and separated from its related species, and data on geographic distribution, ecology and conservation is also provided.

\section{Taxonomic treatment}

Cypella cruenta Deble, sp. nova Typus: BRAZIL. Rio Grande do Sul: Bagé, Pedra Grande, 28 October 2018, L.P.Deble \& M.I.PazDeble 18899 (Holotypus: PACA!). Figures 1, 2. Planta gracilis, $15-50 \mathrm{~cm}$ alta. Bulbus subglobosus, $8-13 \mathrm{~mm}$ longum et $10-14 \mathrm{~mm}$ latum; tunicis castaneis vestitas et in pseudocollum usque $5 \mathrm{~cm}$ longum. Folia basalia ad anthesis absenti vel pauca; lamina plicata, convoluta, anguste linearia, $15-55 \mathrm{~mm}$ longa et $0.05-0.3$ $\mathrm{cm}$ lata. Folia caulinaria anguste linearia $11-38 \mathrm{~cm}$ longa et $0.05-0.3 \mathrm{~cm}$ lata. Caulis floriferus $11-42 \mathrm{~cm}$ longis, simplex vel superne bifurcatis vel trifurcatis, bracteis 1-2 instructi rhipidios pedunculatos originantes. Spatha $1-2$, rare 3, uniflora, $3.2-4.6 \mathrm{~cm}$ longa et $0.2-0.3 \mathrm{~cm}$ lata. Valva externa $1.8-2.6 \mathrm{~cm}$ longa, interiora convoluta

\footnotetext{
Accepted on January 10, 2021.

${ }^{1}$ Universidade Federal do Pampa - Unipampa campus Dom Pedrito, Rua 21 de abril 80, CEP 96450-000. E-mail: deble.biol@gmail.com (author for correspondence).

${ }^{2}$ Núcleo de Pesquisas Botânicas Balduíno Rambo, Universidade Federal de Santa Maria, Av. Roraima, CEP 97105-900.
} 
$3.2-4.4 \mathrm{~cm}$ longa. Pedicellus valva interiora haud excedens, saepe valde brevior. Ovarium obovato-oblongum, 6-7 mm longum. Perigonium luteo-aurantiacum vel aurantiacum conspicue cruento-maculatum, circa 40-50 $\mathrm{mm}$ latum. Tepala exteriora oblonga, pandurata, 26-30 $\mathrm{mm}$ longa, inferiora unguicula dense cruenta maculata. Tepala interiora arcte geniculata et recurvato-reflexa, 9-10 mm longa et 6-7 mm lata, unguicula patentia, fusco-purpureo-striolata; lamina nigro-purpureo vel brunneo-purpureo-striolata. Filamenta $1.8-2.2 \mathrm{~mm}$ longa, obclavata, purpurata, ad base distincte incrassatam, breve connata. Antherae oblongae, 5-5.5 mm longae et 2-2.5 mm latae, connectivo crassiusculo, $2-2.3 \mathrm{~mm}$ lato. Stylus pallide aurantiacum, $8.5-9.5 \mathrm{~mm}$ longus. Styli rami ascendenti erectisve, $2-2.5 \mathrm{~mm}$ longi, basi connati. Cristae adaxiales breves, falcatae, $1.5-2.8 \mathrm{~mm}$ longae, abaxiali minuta. Capsula obovato-oblonga, $10-15 \mathrm{~mm}$ longa et 3.5-5 mm lata. Semina angulata, obovate, circa $2 \mathrm{~mm}$ longa, epidermis minute faveolatis.

Description - Herb 15-50 cm tall, underground stems $2-7 \mathrm{~cm}$ long. Bulb subglobose, small, 8-13 $\times 10-14 \mathrm{~mm}$, prolonged in a collar $2-5 \mathrm{~cm}$ long; cataphylls dark-brown, broadly ovate-lanceolate, apex long acuminate. Basal leaves at anthesis absent or up to 4 , blades narrowly linear, plicate, convolute, $15-55 \times 0.05-0.3 \mathrm{~cm}$. Cauline leaf narrowly linear, $11-38 \times 0.05-0.3 \mathrm{~cm}$, base attenuate. Flowering stems $11-42 \mathrm{~cm}$ long, unbranched or 2-3-branched in distal half. Spathes 1-2 (3) per branch, $3.2-4.6 \times 0.2-0.3 \mathrm{~cm}$, herbaceous, pallid-green, bivalved, one-flowered, pedunculate, peduncles $2-4.5 \mathrm{~cm}$ long; outer valve $1.8-2.6 \mathrm{~cm}$ long, the inner $3.2-4.4 \mathrm{~cm}$ long, both obtuse at the top, apiculate, with membranous and hyaline margin; edges with purple parallel grooves and with greenish-brown or purplish-brown macula; pedicel filiform, 3-4.5 cm long. Flowers 40-50 $\mathrm{mm}$ diameter, predominately golden-yellow or orange, shiny, the concave part reddish-brown painted, with a macula dark-purple in the proximal part; central concavity $15-22 \mathrm{~mm}$ diameter, and 6-8 $\mathrm{mm}$ deeper. Tepal whorls notably dissimilar. Outer tepals oblong, 26-30 mm long, golden-yellow or orange, orange or reddish-orange veined, concave at the base for $c a .10 \mathrm{~mm}$; blades golden-yellow or orange, reddish-brown painted in the proximal third, 16-20 × 14-16 $\mathrm{mm}$, slightly patent or revolute, apices truncate or rounded, apiculate; claws cuneate, $8-9 \mathrm{~mm}$ long, 2.5-3 mm wide at the base, and 8-9.5 $\mathrm{mm}$ wide at the apex, reddish-brown, with a central stripe dark reddish-brown at the base. Inner tepals geniculate-recurved, 9-10 × 6-7 mm long, the proximal half patent, slightly inclinate, then curved upward, the distal one-third incurved and strongly reclinate; blades yellow, with a white-cream central depression densely covered with golden-yellow or bright-yellow one-celled lipid trichomes at the base (carpet of elaiophores), surrounded by a lateral high part, with purplish-brown parallel stripes and few stains; claws cuneate, 7-7.5 mm long, $c a .2 \mathrm{~mm}$ wide at the base, and $3.5-4 \mathrm{~mm}$ wide at the apex, reddish-brown, with dark-purple stripes. Filaments obclavate $1.8-2.2 \mathrm{~mm}$ long, erect, reclined at top, purple, base thickened, purple or reddish-brown, attached for $0.1-0.2$ $\mathrm{mm}$; anthers broadly oblong 5-5.5 × 2-2.5 mm; connective pallid yellowish-orange, $1.8-2.3 \mathrm{~mm}$ wide, thecae darker, pollen golden-yellow. Ovary obovate-oblong, pallid-green, 6-7 × 1.5-2 mm. Style golden-yellow or orange become whitish-cream towards at the base, $8.5-9.5 \mathrm{~mm}$ long. Style branches channeled, almost erect, 2-2.5 mm long, connate in proximal half, with transverse stigmatic surface of the abaxial crest extending one in the each other crest at the apex, translucent and orange, adaxial crests falcate, $1.5-2.8 \mathrm{~mm}$ long, abaxial crest deltate, at apex slightly acute, 0.5-1.3 mm long. Capsule obovate-oblong, 10-15 $\times 3.5-5 \mathrm{~mm}$. Seeds obconic, ca. $2 \mathrm{~mm}$, angled, reddish-brown, epidermis minutely faveolate.

Etymology - The epithet cruenta means bloody or covered in blood, and refers to the perigone color, which is conspicuously stained of reddish-brown.

Additional specimens examined (paratypi)BRAZIL. Rio Grande do Sul: Bagé, Passo do Cassão, em afloramento rochoso, associado a arbustos, 04 November 2018, L.P.Deble \& M.I.Paz-Deble 18901 (PACA!). Caçapava do Sul, em afloramento rochoso, na orla da vegetação arbustiva, próximo ao rio Camaquã, 28 October 2018, L.P.Deble \& M.I.Paz-Deble 18900 (PACA!).

Geographic distribution and habitat- Cypella cruenta was found in humid rocky outcrops, close to shrub formations in the Camaquã River basin, between the municipalities of Bagé and Caçapava do Sul, in the southeastern Rio Grande do Sul state, Brazil. Only three populations were found, in an extension of occurrence less than $500 \mathrm{~km}^{2}$. Although having few records, this species may be more common in the region, considering that the said site is one of the best preserved in the state of Rio Grande do Sul, and most of this region 
Deble, L.P., Cypella cruenta.

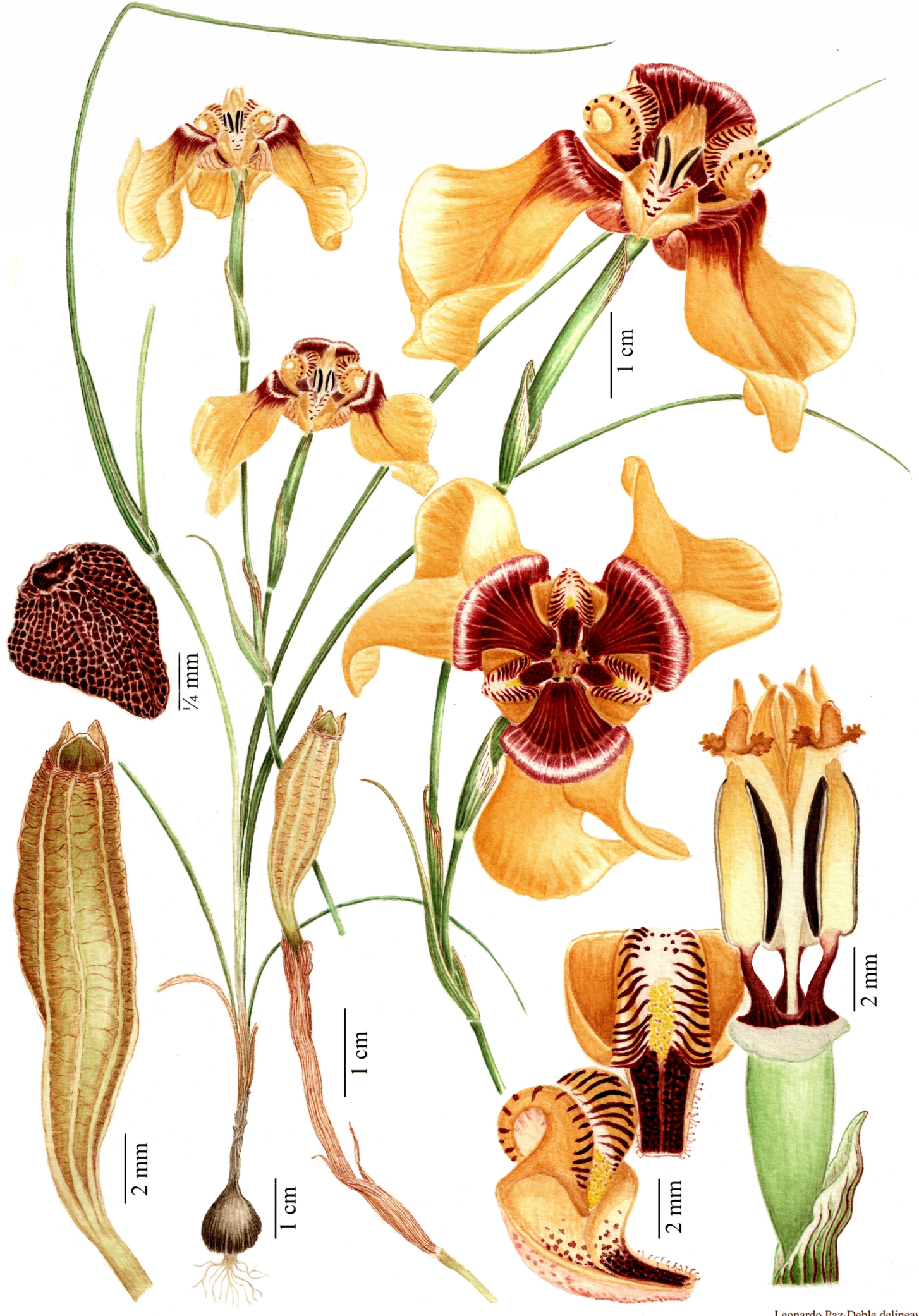

Figure 1.Cypella cruenta. Habit, Detail of infloresce, and Spathe with mature fruit. Lower right, Flower with tepals removed, and inner tepals, frontal and lateral view. Lower left, Fruit. Left, Seed. All from material cultivated from the Holotype. 
is sparsely populated, composed mainly of family ranchers (Borba \& Trindade 2009, Borba 2016), and many of the places that result in the preferred habitat of $C$. cruenta, are steep and difficult to access.

\section{Ecology, size of populations and natural history-} Cypella cruenta is a very rare species, growing in cracks of humid rocky outcrops, under diffuse light, on the edge of shrub-tree formations associated to rocky environments. The majority of the species of Cypella grow in full sun, inhabiting from dry and rocky places, to small streams and moist soils; however, according Deble \& Alves (2017a) there are few species that grow in half shade, either associated with trees or small shrubs, among them Cypella Alonsoana Deble \& Alves (2017: 2) and C. magnicristata Deble in Deble et al. (2012: 63) or on the edge of forest formations, as Cypella parviflora Ravenna ex Deble \& Alves (2017: 6). C. cruenta is only the fourth species of the genus that has this preferred habitat. Only three populations of $C$. cruenta are known, all of them containing less than 30 individuals. The species blooms and bears fruit during the spring, its flowers open only once, in the early morning and wither in the early afternoon. The specimens bloom intensely and produce fruits and seeds abundantly. During our field activities was observed species of bee (Meliponinae) and hoverfly (Syrphidae) hovering or nectaring at flowers. Other species of Iridaceae occurring in the same region are Cypella exilis Ravenna (1981a: 492), C. fucata Ravenna (1981b: 18), C. pusilla (Link \& Otto 1828: 125) Jackson (1893: 689), Herbertia lahue (Molina 1810: 110) Goldblatt (1978: 379), H. caerulea (Herbert 1840: pl. 3779) Herbert (1841: pl. 3862), H. pulchella Sweet (1829: pl. 222), H. zebrina Deble (2010: 93), Kelissa brasiliensis (Baker 1877: 134) Ravenna (1981c: 106) and Sisyrinchium spp.

Conservation-Cypella cruenta is exclusive in humid rocky outcrops, close to shrub formations, and seemingly restrict to the Camaquã River basin, between the municipalities of Bagé and Caçapava do Sul, in the southeast Rio Grande do Sul state, Brazil. Only three populations were found, in an extension of occurrence less than $500 \mathrm{~km}^{2}$. These populations contain less than 30 individuals and the total of mature specimens known is smaller than 100 . The sites of occurrence of $C$. cruenta are difficult to access and are well preserved, considering the current use only for grazing. Nevertheless, the strong advance of economic activities such as mining puts at risk the quality of habitat and the conservation of this species and the others species that are also restricted to the region. Based on the criteria of IUCN (2017) as extension of occurrence, number of populations, quality of habitat, and threats observed C. cruenta should be considered Endangered (EN B1+B2a, b(i, ii, iii, iv) + D).

Uses-Cypella cruenta proves to be suitable for use as an ornamental plant. Its flowers are beautifully stained with blood-red, and the species adapts well to growing in pots, in half shade, with a substrate rich in organic matter.

Discussion - Cypella cruenta is morphologically similar to Cypella exilis, being easily separated by its narrower leaves, $0.05-0.3 \mathrm{~cm}$ wide (vs. $0.15-0.6 \mathrm{~cm}$ wide), flowers with central depression entirely reddish-brown painted (vs. golden-yellow with a purple basal stain, and irregular spots along the concavity), base of the blade densely reddish-brown stained (vs. with a narrow central band, reddish-brown or purple that extends to the middle of the blade), narrower inner tepals $(6-7 \mathrm{~mm}$ width $v s .8-10 \mathrm{~mm}$ width), stamens with filaments of 1.8-2.2 mm long (vs. 2.5-4.5 mm long) and anthers smaller (5-5.5 $\mathrm{mm} v s .5 .5-7 \mathrm{~mm}$ ) with connective of $1.8-2.3 \mathrm{~mm}$ width (vs. 0.7-1.2 mm width), and shorter adaxial crests of style (1.5-2.8 mm vs. 3-5 mm). C. cruenta shows relationship with $C$. Alonsoana, due to the size and color of the flowers, the shape and color of the stamens and the shape of the style. However, $C$. cruenta can be easily separated from $C$. Alonsoana by its one-flowered spathe ( $v s$. two-flowered), by its inner tepals with 6-7 mm wide (vs. 10-11 $\mathrm{mm}$ ), and by the obclavate shape of the filaments (vs. strap-like shaped). C. cruenta is also similar to $C$. fucata, considering the habit, size and shape of the flowers, and the appearance of the stamens and style. However, $C$. cruenta differs from $C$. fucata by its flowers with central concavity entirely reddish-brown stained (vs. ochraceous-yellow, with a smaller purple stain towards the base), stamens with slender filaments, which are purple or reddish-brown colored for the most part of its length ( $v s$. thicker filaments, pale-pinkish or pale-yellowish, with some lines and purple marks only at the base), bigger anthers (5-5.5 vs. 3.2-4.5), and style with shorter crests $(1.5-2.8 \mathrm{~mm}$ vs. $3.5-5.3 \mathrm{~mm})$. 

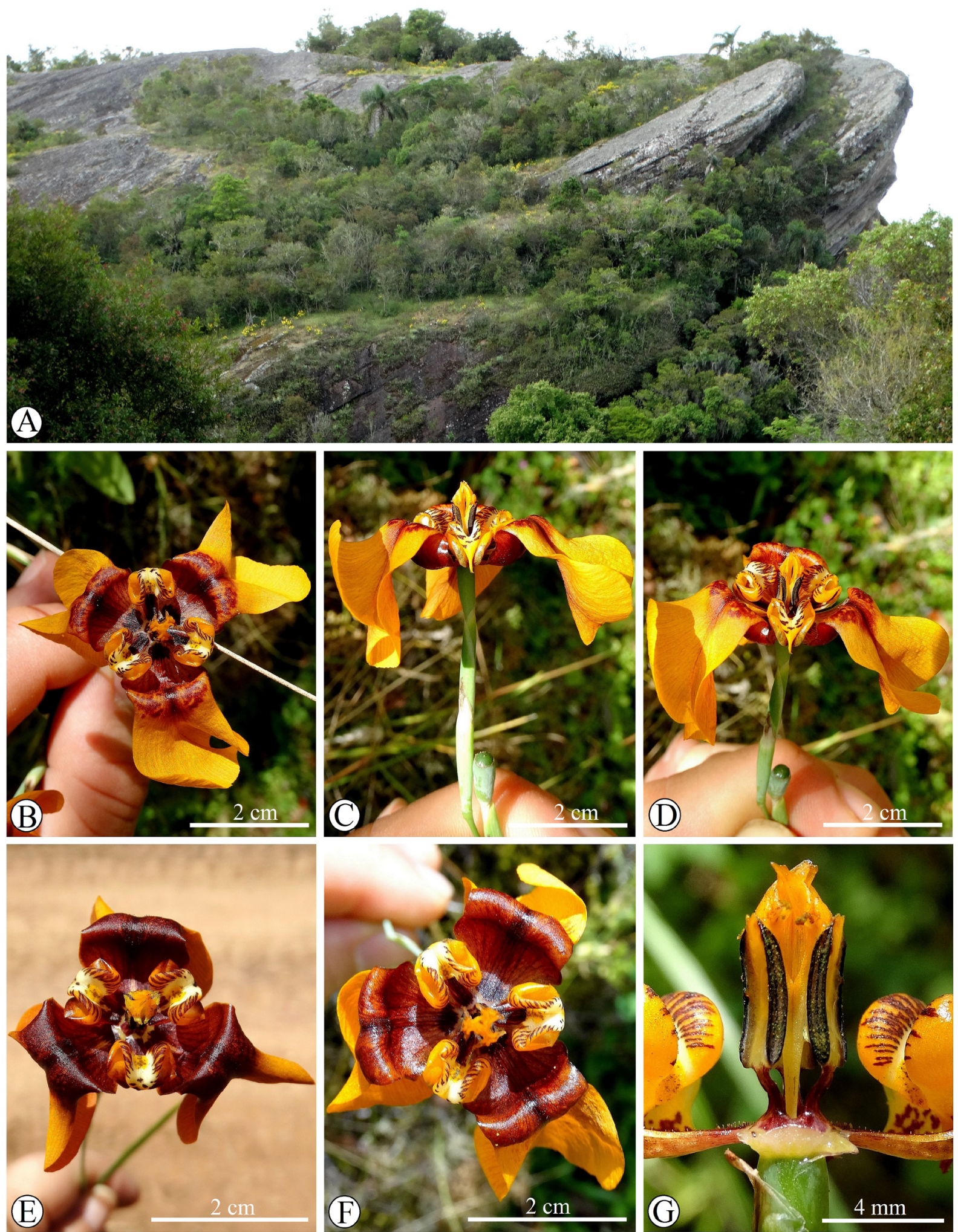

Figure 2. Local of occurence, and details of flowers of Cypella cruenta (A-G). A. Locality of Pedra Grande, north Bagé municipality. B. Flower, frontal view. C. Flower, lateral view. D. Flower, inclined view. E. Flower frontal view. F. Flower, frontal view. G. Flower, tepals removed. (B-D, G from Holotype, E and F from L.P.Deble \& M.I.Paz-Deble 18900, 18901). 
Deble, L.P., Cypella cruenta.

Table 1. Characteristics to distinguish Cypella cruenta from it allies

\begin{tabular}{|c|c|c|c|c|}
\hline Character/Species & C. cruenta & C. Alonsoana & C. exilis & C. fucata \\
\hline Plant height (cm) & $15-50$ & $38-90$ & $10-60$ & $12-25$ \\
\hline Size of spathes $(\mathrm{cm})$ & $3.2-4.6 \times 0.2-0.3$ & $3.1-4.5 \times 0.4-0.6$ & $4.1-5.8 \times 0.3-0.4$ & $2.8-3.4 \times 0.2-0.3$ \\
\hline $\begin{array}{l}\text { Peduncles of spathes lenght } \\
\text { (cm) }\end{array}$ & $2-4.5$ & $2.1-6.5$ & $2.4-3.8$ & $1.2-3$ \\
\hline Flower per spathe & 1 & 2 & 1 & 1 \\
\hline $\begin{array}{l}\text { Perigone color, aspect and } \\
\text { diameter }(\mathrm{mm})\end{array}$ & $\begin{array}{l}\text { golden-yellow or orange, the } \\
\text { concave part reddish-brown, } \\
40-50\end{array}$ & $\begin{array}{l}\text { golden-yellow, the concave } \\
\text { part with purple paints, } \\
35-45\end{array}$ & $\begin{array}{l}\text { golden-yellow or orange, } \\
\text { blade with dark-purple } \\
\text { longitudinal strip, concave } \\
\text { part with dark-purple paints, } \\
42-60\end{array}$ & $\begin{array}{l}\text { dull-orange or ochraceous-or- } \\
\text { ange, concave part with dark } \\
\text { purple paints, } 25-40\end{array}$ \\
\hline $\begin{array}{l}\text { Central concavity size } \\
(\mathbf{m m})\end{array}$ & $15-22 \times 6-8$ & $18-23 \times 5-6$ & $15-20 \times 7-9$ & $10-12 \times 5-6$ \\
\hline $\begin{array}{l}\text { Outer tepal shape and size } \\
(\mathrm{mm})\end{array}$ & oblong, 26-30 & oblong, $35-42 \times 16-22$ & $\begin{array}{l}\text { oblong or obovate-oblong, } \\
26-40 \times 16-25\end{array}$ & $\begin{array}{l}\text { obovate or obovate-oblong, } \\
17-25 \times 10-12\end{array}$ \\
\hline Inner tepal size $(\mathrm{mm})$ & $9-10 \times 6-7$ & $10-11 \times 10-12$ & $10-11 \times 8-10$ & $7.5-8 \times 6-7$ \\
\hline $\begin{array}{l}\text { Anthers shape and size } \\
(\mathrm{mm})\end{array}$ & $\begin{array}{l}\text { broadly oblong } 5-5.5 \times \\
2-2.5\end{array}$ & $\begin{array}{l}\text { broadly oblong } 5.5-6.3 \times \\
2-2.6\end{array}$ & oblong, $5.5-7 \times 1.3-1.6$ & $\begin{array}{l}\text { broadly oblong, } 3.2-4.5 \times \\
1.8-2.2\end{array}$ \\
\hline Connective width (mm) & $1.8-2.3$ & $1.8-2.4$ & $0.7-1.2$ & $1-1.4$ \\
\hline $\begin{array}{l}\text { Filaments color, shape and } \\
\text { length }(\mathrm{mm})\end{array}$ & purple, obclavate $1.8-2.2$ & $\begin{array}{l}\text { purplish-cream, tape-shaped, } \\
2.2-2.8\end{array}$ & $\begin{array}{l}\text { pale-pinkish or pale-yellow- } \\
\text { ish, purples stripes at base, } \\
\text { obclavate, } 2.5-4.5\end{array}$ & $\begin{array}{l}\text { pale-pinkish or pale-yellow- } \\
\text { ish, obclavate, } 1.8-2.1\end{array}$ \\
\hline $\begin{array}{l}\text { Style length (including style } \\
\text { branches and crests) (mm) }\end{array}$ & $8.5-9.5$ & $11.5-12.5$ & $12.5-14.5$ & $11-13.5$ \\
\hline Style branches length (mm) & $2-2.5$ & $2-2.8$ & $2.5-3.8$ & $\begin{array}{l}2-3 \text { (often fused in its prox- } \\
\text { imal half) }\end{array}$ \\
\hline $\begin{array}{l}\text { Adaxial crests shape and } \\
\text { length }(\mathrm{mm})\end{array}$ & falcate, $1.5-2.8$ & falcate, $3.8-4.6$ & lanceolate, 3-5 & lanceolate $3.5-5$ \\
\hline $\begin{array}{l}\text { Abaxial crest shape and } \\
\text { length }(\mathrm{mm})\end{array}$ & deltate, $0.5-1.3$ & deltate, $1.8-2$ & deltate, $1-2$ & ovate at apex bifid, $0.5-1$ \\
\hline $\begin{array}{l}\text { Stigmatic portion color and } \\
\text { aspect }\end{array}$ & $\begin{array}{l}\text { ochraceous orange, extend- } \\
\text { ing for ca. } 1 \mathrm{~mm} \text {, strongly } \\
\text { patent }\end{array}$ & $\begin{array}{l}\text { light-yellow, extending for } \\
\text { ca. } 0.5 \mathrm{~mm} \text {, slightly patent }\end{array}$ & $\begin{array}{l}\text { purplish-orange or pur- } \\
\text { plish-brown, extending for } \\
\text { ca. } 1 \mathrm{~mm} \text {, strongly patente }\end{array}$ & $\begin{array}{l}\text { ochraceous orange, extend- } \\
\text { ing for ca. } 0.2-0.3 \mathrm{~mm} \text {, } \\
\text { slightly patent }\end{array}$ \\
\hline Habitat & $\begin{array}{l}\text { humid rocks, among tree and } \\
\text { shrubby community }\end{array}$ & $\begin{array}{l}\text { dry grasslands, among tree } \\
\text { and shrubby community }\end{array}$ & grasslands & $\begin{array}{l}\text { dry grasslands and rocky } \\
\text { places }\end{array}$ \\
\hline Geographic distribution & $\begin{array}{l}\text { Southern Rio Grande do Sul, } \\
\text { Brazil }\end{array}$ & Northern Uruguay & $\begin{array}{l}\text { Southern Brazil (RS, SC), } \\
\text { and Uruguay }\end{array}$ & $\begin{array}{l}\text { Uruguay, northeast Argenti- } \\
\text { na and Rio Grande do Sul, } \\
\text { Brazil }\end{array}$ \\
\hline
\end{tabular}

Comments about the type of Cypella exilis and the analysis of dry material of this species, $C$. cruenta and C. fucata - The identity of Cypella exilis was addressed in several studies since its original description as Polia gracilis Klatt (1862: 545), which was based on collections made by Sellow in Rio Grande do Sul (Brazil) and Uruguay, to information later that ended up confusing the true identity of this species (Klatt 1871, Baker 1877, Baker 1892, Ravenna 1965). Baker (1877) transferred Polia gracilis to Cypella; however, under an illegitimate name, thus Ravenna (1981a) proposed the new name $C$. exilis for this taxon. However, it was only recently that the species was typified, based on the original collections analyzed by Klatt, and mentioned in 1862 (Deble \& Alves 2017, Deble 2017). Deble \& Alves (2017b) when typifying $C$. exilis signposted the possible collection site, according to Urban (1893: 196) in which "the collection Sellow d.2077 was made between the current municipalities of Aceguá and Pelotas" the authors indicated that "three species of Cypella sect. Cypella occur within this area: C. fucata, C. Herbertii and C. amplimaculata". Based on the analysis of the type of $C$. amplimaculata Chauveau \& Eggers in Chauveau et al. (2014), they considered this species as conspecific with $C$. exilis, based on the darker central line of the outer tepals and the overlapping measures of the floral parts. Even with the lectotype being a complete exsiccate, Eggers et al. (2019) considered $C$. exilis doubtful, but Deble \& Alves (2020) maintained this species as the valid name for $C$. amplimaculata. With the addition of a new species 
for the same region of occurrence of $C$. exilis, a new analysis of the type of this species was necessary. For this, the images provided by Jstor (2020) were used, which have high resolution and have a very accurate measurement tool. Thus, it was verified that the lectotype of $C$. exilis displays anthers of $6.8 \mathrm{~mm}$ long, with connective of $0.9-1$ $\mathrm{mm}$, and staminal filaments with $c a .3 \mathrm{~mm}$. The characteristics of the type of $C$. exilis, including the measurements of the floral parts, leave no doubt about the maintenance of $C$. amplimaculata as a synonym for $C$. exilis, as already indicated in previous works (Deble \& Alves 2017b, Deble 2017, Deble \& Alves 2020). C. cruenta, in turn, is a taxon of easy recognition, even in dry material, in view of the smaller size of the anthers, the broad connective and the appearance of the external tepals, which become violet in dry material. In $C$. exilis the tepals dry straw-colored, having a darker conspicuous longitudinal central line, whereas in C. fucata they also dry straw-colored, but the veins remain distinctly darker and the darker central line is absent.

\section{Considerations}

Cypella cruenta is a new species for the section Cypella, related mainly to $C$. exilis, but which differs from this species by relevant morphological characteristics as the basal part of the blade, which is entirely reddish-brown stained, by the stamens with shorter filaments and smaller anthers, by the style with briefer branches and shorter crests, and by the different shape of the style crests. $C$. cruenta is also related to Cypella Alonsoana and C. fucata; however, it can be easily separated from the first-one species by its one-flowered spathes, while from C. fucata the new species can be readily recognized by the bigger anthers and shorter crests, and mainly by perigone with central concavity entirely reddish-brown stained. With the description of Cypella cruenta the genus Cypella now comprises 32 species, and the section Cypella currently encompasses 17 species, most of which are threatened and exclusive to the Campos eco-region (delimitation of the grasslands eco-regions following Azpiroz et al. 2012). C. cruenta occurs in clearing rocky sites among shrubby community and trees, and probably this species not occurs in full sun. The ecological data mentioned evidence that $C$. cruenta require specific habitat and its range of occurrence demonstrate that this species in exclusive in the region of Camaquã river basin, in southeastern Rio Grande do Sul state, Brazil. As evidenced, Cypella cruenta is more one taxon endemic in the Campos eco-region of the complex ecosystems of Río de La Plata Grasslands (following the delimitation of Soriano et al. 1992, Bilenca \& Miñarro 2004, Azpiroz et al. 2012), and reinforce the necessity of actions that subsidize the valuation and conservation of these environments.

\section{References}

Azpiroz, A.B., J. P. Isacch, R.A. Dias, A.S. Di Giacomo, C.S. Fontana, \& C.M. Palarea. 2012. Ecology and conservation of grassland birds in southeastern South America: a review. Journal of Field Ornithology 83: 217-246.

Baker, J.G. 1877. Systema Iridacearum. Journal of Linnean Society, Botany 16: 61-180. http://dx.doi. org/10.1111/j.1095-8339.1877.tb00172.x

Baker, J.G. 1892. Handbook of the Irideae. London: George Bells \& Sons, 248 pp. http://dx.doi.org/10.5962/bhl. title. 15431

Borba, M.F.S. \& J.P.P.Trindade. 2009. Desafios para a Conservação e a valorização da Pecuária Familiar: 391-403. In: Pillar, V. P., S.C. Müller, Z.M. de S. Castilhos, A.V.A. Jacques. Campos Sulinos: Conservação e Usos Sustentável da Biodiversidade. MMA, Brasília.

Borba, M.F.S. 2016. Desenvolvimento Territorial Endógeno: o caso do Alto-Camaquã: 187-214. In: Waquil, P.D., A. Matte, M.Z. Neske, M.F.S. Borba, Pecuária Familiar no Rio Grande do Sul: História, Diversidade Social e Dinâmica de Desenvolvimento: Editora UFRGS, Porto Alegre.

Bilenca, D. \& F. Miñarro. 2004. Identificación de áreas valiosas de pastizal en las Pampas y Campos de Argentina, Uruguay y Sur de Brasil.Buenos Aires: Fundación vida silvestre, $353 \mathrm{pp}$.

Chauveau, O., T. Pastori, T.T. Souza-Chies \& L. Eggers. 2014. Overlooked diversity in Brazilian Cypella (Iridaceae, Iridoideae): four new taxa from the Río de la Plata grasslands. Phytotaxa 174 (1): 25-42.

Deble, L.P. 2010. Herbertia zebrina (Iridaceae, Tigridieae, Cipurinae) a new species from Rio Grande do Sul state, Brazil. Darwiniana 48 (1): 93-96.

Deble, L.P. 2017. La identificación de Cypella exilis Ravenna (Iridaceae). Balduinia 56: 27-34.

Deble, L.P., A.S. de Oliveira \& F.S. Alves. 2012. Two new species of Cypella (Iridaceae: Tigridieae) from Rio Grande do Sul, Brazil. Phytotaxa 71: 59-68.

Deble, L.P. \& F.S. Alves. 2017a. The type of Cypella herbertii subsp. brevicristata Ravenna (Iridaceae: Tigridieae). Balduinia 56: 20-26.

Deble, L.P. \& F.S. Alves. 2017b. Taxonomic novelties for the genus Cypella (Iridaceae): new species, synonymies and nomenclatural types. Kew Bulletin, Kew, vol. 72 (41): $1-18$.

Deble, L.P. \& F.S. Alves. 2020. Cypella (Iridaceae) What do we know about the diversity of the genus? Balduinia 66 : 2-27.

Eggers, L., R. Marchioretto, T.T. Souza-Chies, \& O. Chauveau. 2019. A Taxonomic synopsis of Cypella (Iridaceae) in Brazil. Acta Botánica brasílica 33: 741-769. 
Deble, L.P., Cypella cruenta.

Goldblatt, P. 1978. Herbertia (Iridaceae) reinstated as a generic valid name. Annals of the Missouri Botanical garden 64: 378-379.

Herbert, W. 1840. Gelasine azurea. Azure Gelasine. Curtis's Botanical Magazine 66: pl. 3779.

Herbert, W. 1841. Herbertia pulchella, et caerulea. Pretty and Blue Herbertia. Curtis's Botanical Magazine 67: pl. 3862 .

IUCN. 2017. Guidelines for using the IUCN Red List Categories and Criteria, version 13. IUCN Red List Unit, Cambridge U.K. Available from: http://www.iucnredlist.org/ documents/RedListGuidelines.pdf (accessed: September 2020).

Jackson, B.D. 1893. Index Kewensis 1: 689.

JSTOR. 2020. Global Plants on JSTOR. Available at: http:// plants.jstor.org/ (accessed: July 2020)

Klatt, F.W. 1862. Specimen e familia Iridacearum. Linnaea 31: 533-570.

Klatt, F.W. 1871. Irideae: 510-548. In: Martius, C.F.P. von \& A. G. Eichler (eds.). Flora Brasiliensis 3 (1). Wolf, C. et fil. \& Minsinger, S., Munich.

Link, J.H.F. \& C.F. Otto. 1828. Ferraria pusilla. Icones plantarum selectarum 10: 125-126.

Molina, G.I. 1810. Saggio sulla Storia Naturali del chili. Bologna, Tommazo d'Aquino. 332pp.
Soriano, A., R.J.C. León, O.E. Sala, R.S. Lavado, V.A. Deregibus, O. Cahuepé, A. Scaglia, C.A.Velazquez, \& J.H. Lemcoff. 1992. Río de la Plata grasslands. In: Coupland, R.T. (Ed.) Ecosystems of the World. Natural Grasslands. Introduction and Western Hemisphere. Elsevier, Amsterdam, p. 367-407.

Sweet, R. 1829. Herbertia pulchella: plaited leaved Herbertia. P1. 222. The British flower garden: containing coloured figures \& descriptions of the most ornamental \& curious hardy herbaceous plants ... London, v. 3.

Ravenna, P.F. 1965. Notas sobre Iridaceae II. Boletin de La Sociedad Argentina de Botanica 10 (4): 311-322.

Ravenna, P.F. 1981a. A submerged new species of Cypella (Iridaceae), and a new section for the genus (s.str.). Nordic Journal of Botany 1: 489-492. http://dx.doi.org/10.1111/j.1756-1051.1981.tb00714.x

Ravenna, P.F. 1981b. Eight new species and two new subspecies of Cypella (Iridaceae). Wrightia 7 (1): 13-21.

Ravenna, P.F. 1981c. Kelissa a new genus of Iridaceae from South Brazil. Adansonia 1: 105-110.

Urban, I. 1893. Biographisce Skizzen. Systematic Pflanzen geschichte und Pflanzen geographie herausgegeben von A. Engler, Leipzig: 178-198. 